\title{
MOVING BEYOND ECONOMIC ANALYSIS: ASSESSING THE SOCIO-CULTURAL IMPACTS OF DISPLACEMENT AND RESETTLEMENT BY SARDAR SAROVAR PROJECT, INDIA
}

\author{
Gaurav Sikka \\ Assistant Professor, University Department of Geography, Lalit Narayan Mithila University, Darbhanga- 846004, \\ Bihar, India \\ *Corresponding author: gauravsikkageo@gmail.com \\ Received: December 9'th 2019 / Accepted: August 9th 2020 / Published: October 15t, 2020 \\ https://DOI-10.24057/2071-9388-2019-165
}

\begin{abstract}
The large scale development projects like dams have been justified for a greater economic benefit of the nation. However, the development projects have become synonymous with land acquisition leading to dispossession and forced migration of a large number of people and their involuntary resettlement. Unfortunately, too much focus on the economic benefits of such large scale projects has omitted many relevant tangible and intangible socio-cultural aspects and ignored the impacts of development policies that shape forced migrations. The present paper asserts to move beyond the 'limited' economic analysis of large projects and includes the critical social and cultural implications of forced migration and displacement. The paper presents views of respondents displaced from the states of Gujarat, Madhya Pradesh and Maharashtra and were resettled in Gujarat. Perhaps, it is the most unique aspect of this paper to understand the socio-cultural adjustment in context of the spatial origin. The resettlement caused by the Sardar Sarovar Project has led to a change in dress patterns and marriage customs, loss of tribal folk art, destroyed the existing social networks and hindered access to new ones. Increased violence against women, problem of drunkenness and bootlegging at the resettlement sites are also highlighted. The insights in the work are based upon the fieldwork in select resettlement sites in Gujarat. The author adopted participant observation, focus group discussions and key informant interviews as a means for data collection and better comprehension of the study area.
\end{abstract}

KEY WORDS: Displacement, Resettlement, Sardar Sarovar Project, Social and Cultural Impacts

CITATION: Gaurav Sikka (2020). Moving Beyond Economic Analysis: Assessing The Socio-Cultural Impacts Of Displacement And Resettlement By Sardar Sarovar Project, India. Geography, Environment, Sustainability.

https://DOI-10.24057/2071-9388-2019-165

Conflict of interests: The author reported no potential conflict of interest.

\section{INTRODUCTION}

Contemporary supporting arguments for large scale projects like dams are developed primarily on the basis of economic analysis. According to Philip (2009), development projects in the early years of Indian independence were marked by infrastructural development and therefore were ideologically committed to the poor. In post-independent India, mega-projects like big dams, towering steel and power plants, mines and ports symbolised the breaking of chains of colonial legacy and of underdevelopment. Thus naturally, the process of dam building was considered equivalent to nation building. It was clear from the start that mega-projects would require displacement or forced uprooting of substantial populations, particularly for hydro projects which entail large-scale submergence for reservoirs. However, national leaders and policy-makers typically viewed these as the legitimate and inevitable cost of development, acceptable in the greater national interest. Pt. Jawaharlal Nehru's zeal for basic industries and «scaling the commanding heights of the economy» (Chattopadhyay 2011) can be put into a perspective here, which was evident in his speeches with statements like «dams are the temples of modern India» (after Indian Independence in 1947) and to the displaced persons of Hirakud Dam in 1948 he said, «If you are to suffer, you should suffer in the interest of the country» (Guha 2005).

Due to low levels of indigenous production in the years after independence and huge dependence on imports of essential commodities like food, energy, it became necessary for the agenda of development to focus on irrigated agriculture and multipurpose river projects for achieving self-sufficiency (Thatte 2012). For many decades after the independence, economic growth was the only focus for every government (CSE 1985) and this economic growth has come to mean a growth with increasing consumption of energy and other resources, energy with electricity, and electricity with centralised large-scale generation, transmission and distribution (Chattopadhyay 2006). This paradigm was used by Narmada Control Authority (NCA) to justify the need for development of hydropower projects. In per capita consumption of electricity which is regarded as one of the indices of measurement of development, India lagged behind in the per capita consumption of the energy (NCA 1990 in Chattopadhyay 2011). Against this backdrop, Sardar Sarovar Project with a planned generation capacity of 1,450 MW of hydropower was considered an 'attractive proposal'. Additionally, it was anticipated by the authorities 
that the dam will irrigate 1.8 million hectares of agricultural land and provide water to the drought-prone areas of Kutch and Saurashtra in Gujarat (Sardar Sarovar Narmada Nigam Limited 2015). In fact, projects like Sardar Sarovar are still seen as «the panacea,'a magical solution' to all the problems of Indian development state» (Dharmadikary 1993).

Unfortunately, too much focus on the economic benefits of such large scale projects has omitted many relevant tangible and intangible social aspects and ignored the impacts of development policies that shape forced migrations. Resettlement would render a serious blow to the indigenous customs and ways of life of the affected persons particularly the tribals (Morse and Berger 1992). A number of economic development policies of developing states regard involuntary resettlement as a necessary and unavoidable cost of development, and the people affected by it as victims of a just cause (Terminski 2013). The notion of 'sacrifice' has influenced thinking on displacement considerably and led to the perception of resettlement and rehabilitation (Bartolome, de Wet, Mander, \& Nagaraj 2000 in Mishra 2019).

In recent decades, attention has been turned upon the displacement caused by development projects, disasters, wars, violence and conflict etc. (Colson 1999; Scudder 1983; Mathur 2009; Chakravorty 2016). Cernea (1996) identified eight risks - landlessness, joblessness, homelessness, marginalisation, increased morbidity and mortality, food insecurity, loss of access to common property and services and social disarticulation - that emerges due to development-induced displacement. A fair resettlement plan should address these risks, keeping the local context in mind.

Development projects have become synonymous with land acquisition leading to dispossession and displacement of a large number of people and their involuntary resettlement in an alien environment. In this context, dams are considered to be the greatest cause of displacement worldwide. For example, dams have displaced 10.2 million people in China between 1950 and 1990 (WCD 2000). The twentieth century has witnessed dam building on an unprecedented and gigantic scale causing major social consequences in the form of displacement of a large number of people. It is maintained that there can be no vikas (development) without vinash (destruction). Since the independence of India in 1947, 21 to 50 million people have been displaced by large projects such as mineral extraction, dams and industrial complexes (Hemadri et al. 2000). According to Asian Development Bank, between 40 million and 80 million people have been forced to leave their homes due to the construction of large hydroelectric dams alone (ADB 1998; WCD 2000). The World Bank estimates that «approximately 10 million people enter the cycle of forced displacement and relocation annually due to either dam constructions or urban/transportation projects alone» (Cernea 1996).

Development-induced displacement or forced migration in the name of development is affecting a greater number of people, as countries move from developing to the developed category. Population subjected to such migrations is often helpless and their voices have been ignored by the authorities and by different lobbies. Rehabilitation of such displaced persons is one of the major challenges before the society.

«International conferences like the Second World Water Forum and organisations like World Commission on Dams (WCD) have generated awareness on the dangers of resettlement for local populations displaced by development and on their ability to re-establish, if not improve, their livelihoods» (Dorcey et al. 1997).

Many studies have documented that projects which cause a large magnitude of displacement are usually justified by the planning authorities on the grounds that they provide tangible economic benefits to a larger number of people (Goyal 1996). For instance, Sardar Sarovar Narmada Nigam Limited claims that against one tribal person being displaced, seven tribals would be benefited. Correspondingly, Bhakra Nangal Dam at the time of a newly independent nation was analogous to patriotism, nation building and economic spurt for the national economy, and overshadowed the sufferings and hardships borne by the next generations of resettlers, who have been forgotten by the nation (Mishra 2019).

However, it is imperative to identify and assess the socio-cultural impacts associated with displacement and resettlement in development projects. A life with dignity for a tribal includes «material goods as well as identity, culture and self-image. Loss of their sustenance is an attack on their whole life because it breaks the close link between land and their economic, political and cultural systems. All these rights are thus interlinked and are to be treated as integral to their right to a life with dignity and included in the definition of indigenous status» (Fernandes 2013). Further, «the indigenous peoples see themselves as 'peoples', with distinct collective rights and distinct historical, political, social, cultural and spiritual identities that unite them. It is through the collective exercise of their right to self-determination that their languages, laws, values, customs, practices, traditions and institutions are maintained and manifest themselves, and which is essential for their practical survival as well» (Whall 2004). Cernea 1999 states that in a paradigm that considers development as the transformation of whole societies, 'social costs' of development interventions need to be analysed. Bose, et al. (2001) while highlighting the importance of Social Impact Assessment (SIA) studies in large infrastructure projects like dams stated that these studies are conducted by the project authorities as a «formality to satisfy monitoring and funding agency requirements». As a result, a cursory treatment is given to socio-economic issues of the projects and goals of social justice are not ensured. The forced displacement cumulates physical exclusion from a geographic territory with economic and social exclusion out of a set of functioning social networks (Cernea 1997).

The process of changes in social-cultural milieu and transformation of traditional customs of the resettlers after displacement have been highlighted by Mukherjee 1990; Reddy 1990; Vyas 1995; Modi 2004; Padel and Das 2008. Mukherjee (1990) analysed that there is degradation in the quality of life of people, displaced by the hydroelectric project at Loktak in Manipur Valley. Keeping the social concerns in mind, Reddy (1990) suggested that the project authorities should think in terms of community resettlement and not in terms of individual resettlement, because tribal communities live as a cohesive whole - a social world that is small in its geographical dimension. Their relations and interactions with humans from society's mainstream are very limited and rare when compared to an urban civilization. Thus, the known social world will provide them the necessary psychological cushion and a coping strategy to adjust to the new situation. Vyas (1995) examined the social consequences of resettlement caused by the Kadana Dam on the tribals of Southern Rajasthan and observed the social effects of compensation economics. Vyas (1995) found that a large number of marriages among the Bhil resettlers were solemnized in the year succeeding cash compensation award and the bride price also increased. Also, Bhils feared that they might not get suitable spouses for their sons/daughters after they were displaced. This caused them to start the practice of child marriages which is quite an uncommon phenomenon among the Bhil community 
(Vyas 1995). Similar changes in marriage traditions were also recorded at the SSP resettlement sites and discussed in succeeding section. Tribal culture exists through relationships ordered by the form of underlying social structure. «Every part of this social structure is torn apart by displacement: the economic system, along with the whole tradition of cultivation is completely destroyed; the kinship system is fractured by displacement from villages, where social relations follow the pattern of spatial layout of villages and spatial distance to neighbouring villages; the religious system is undermined by removal of sacred sites; material culture is destroyed as houses made of local material are being replaced with concrete houses; above all the power structure is transformed, from being the owners of the area and its resources, people find themselves at the bottom of the hierarchy of power and social authority» (Padel and Das 2008). A new social poverty may be seen everywhere - in lives wrecked, social relationships realigned, social and economic assets lost, leaders toppled, people - particularly elderly people - growing ill and dying prematurely, and the diminished capacity of a society to withstand nonproject related threats (Cernea 1995, 2000; de Wet 2006). Such social and cultural impacts can be recorded, but their mitigation dynamics cannot be understood easily. Modi (2004), in a longitudinal assessment of Sardar Sarovar Project resettlement sites brought to fore that the resettler's way of life is lost which is evident from the fact that families/ villages were scattered over various resettlement sites due to a shortage of land, breaking up families and community networks they drew upon for exchange of food, tools and services such as ex-change of labour. It should be understood that tribals are deeply attached to their socio-cultural settings and ecology. Thus, moving to new places is just unthinkable for the tribals. In fact, the word 'resettlement' does not exist in many tribal languages (Escudero 1988 quoted in Dalal 2011).

Most studies on the effect of resettlement of oustees in the Narmada Valley by SSP have been conducted in the 1980s and 1990s and focus on the process of resettlement or the well-being of the oustees soon after resettlement (Scudder 1983; Baviskar 1995; Hakim 1997). These studies have raised important concerns that indicated that resettlement will not succeed and rehabilitation will be a distant dream. After two decades of resettlement, as Aiyar and Kaushal (2018) put forth, the studies are required to highlight the problems of second generation (Sah 2003) at the resettlement issues.
Multi facet studies have detailed on the environment sustainability, social and cultural issues, gender concerns, economic impacts on livelihood and other R\&R deficiencies (Hakim 1997; Dwivedi 1999; Cernea 2000; Chattopadhyay 2010; Sah and Tomar 2011). It is imperative to understand the long-term impacts of displacement on the resettlers. The analysis presented in this paper on socio-cultural impacts of displacement and resettlement on the resettlers adds to the existing literature and presents a perspective to understand the long-term impacts of displacement on the resettled population. The present paper asserts to move beyond the 'limited' economic analysis of large projects and includes the critical social and cultural aspects of forced migration and displacement. The paper presents views of respondents displaced from the states of Gujarat, Madhya Pradesh and Maharashtra and were resettled in Gujarat. Perhaps, it is the most unique aspect of this paper to understand the sociocultural adjustment in context of the spatial origin.

Interestingly, mitigation of economic consequences of displacement like restoration of livelihood, recovery of losses, skill upgradation etc. has been focussed (Downing 2002) however, less attention has been paid to the noneconomic, psycho-socio-cultural impoverishment inflicted by involuntary displacement (Cernea 2000; de Wet 2006). Furthermore, the funding agencies like World Bank have shaped resettlement practices in many recipient countries. The subsequent resettlement iterations in form of the Operational Manual 4.30 (1990), Operational Manual 4.12 (2001) (Clark 2007, 2009) and the Environment and Social Framework (Standard 5) in 2017 have emphasised upon environmental, social and cultural implications of the projects with aim of better protecting the oustees.

\section{Study Area}

Sardar Sarovar Project, a large multipurpose river project on river Narmada has displaced more than 40,000 families, primarily tribals from the 245 villages spread over three states of Gujarat, Madhya Pradesh and Maharashtra. The forced displacement and resettlement have put the lives of these development refugees in transition. Sardar Sarovar has been planned for generating 1,450 MW of electricity and to quench the water needs of the people of Kachchh, Kathiawar, North Gujarat and Southern part of Rajasthan (Fig. 1).

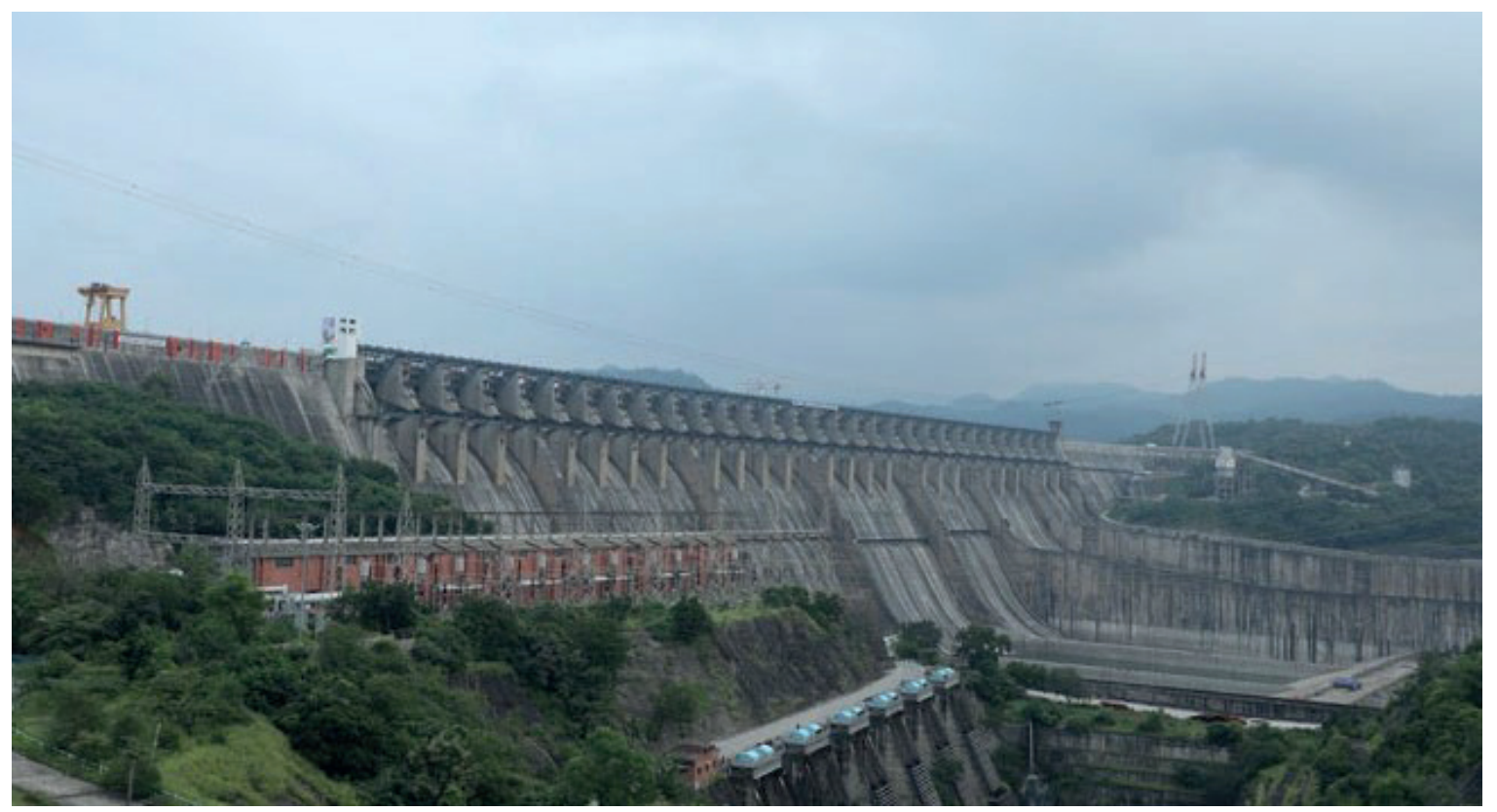

Fig. 1. Sardar Sarovar Project at its full height of 138 metre on 17 Sept. 2017 
Majority of the resettlers are tribals belonging to tribal communities like the Tadvi, Vasava, Raathwa and Bhilala etc. These resettled people were taken as the subject of the present study.

To resettle these affected people, around 200 resettlement sites were developed by the Sardar Sarovar Punarvasvat Agency (SSPA) in Gujarat. Maximum number of these sites is located in Vadodara district.

\section{Extent of Spatial Displacement in Sardar Sarovar Project}

According to the World Commission on Dams' final Report (2000), between 40 and 80 million people worldwide have been displaced by the construction of dams alone.

In fact, India has become the third largest dam-builder country with around 4000 dams, consequentially dam induced displacement has become a 'common' problem in India. Sardar Sarovar Dam on Narmada River in Gujarat is one of those dam projects that has caused widespread displacement of people. In 1979 the number of families that would be displaced by the Sardar Sarovar Reservoir was estimated to be a little over 6000. In 1987 this figure rose to 12000. In 1991 it surged to 27000. In 1992 the Government declared that 40000 families would be affected. Till 2000, it was around 41000 families. As per recent estimates by SSNL, 46507 families have been affected. But according to the NBA (Narmada Bachao Andolan) the actual figure is 85000 families - about half a million people.

The following table 1 shows the number of villages and families affected due to submergence by Sardar Sarovar Project in all the three affected states. A total of 245 villages have been affected by the submergence, out of this - 19 lie in Gujarat, 33 in Maharashtra and 193 in Madhya Pradesh (Fig. 2).

\section{METHODOLOGY}

The research paper is based on a recently completed research for which the field surveys of the selected sites were carried out in November 2015 - January 2016.
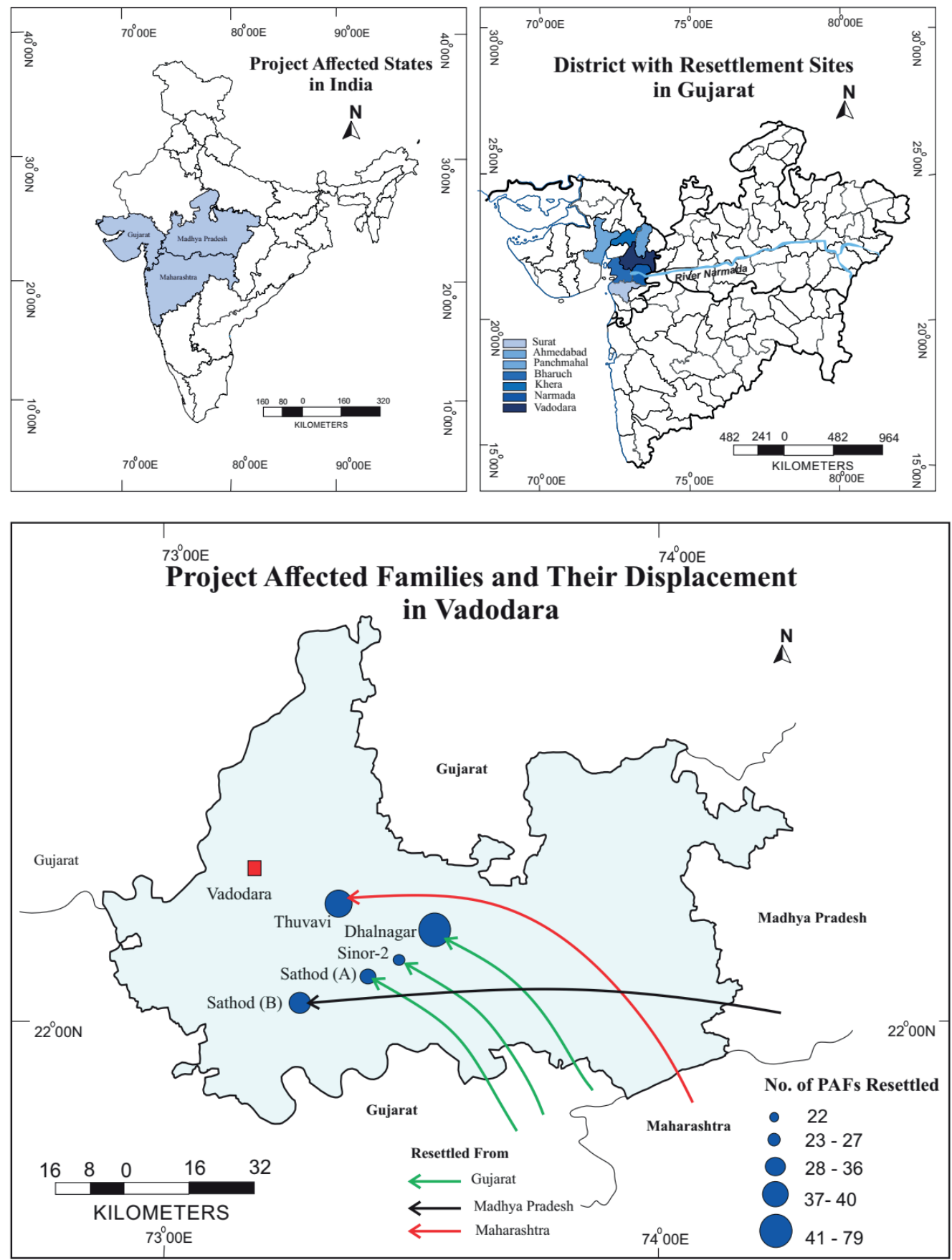

Fig. 2. Origin of Project Affected Families from M.P., Maharashtra and Gujarat and their Resettlement in Sample Resettlement Sites 
Table 1. Figures Related to Submergence Affected Areas in the SSP

\begin{tabular}{|c|c|c|c|c|c|c|c|}
\hline State & $\begin{array}{c}\text { Villages Fully } \\
\text { Submerged }\end{array}$ & $\begin{array}{c}\text { Villages } \\
\text { Partially } \\
\text { Submerged }\end{array}$ & $\begin{array}{c}\text { Total Villages } \\
\text { Affected }\end{array}$ & $\begin{array}{c}\text { Families } \\
\text { Affected }\end{array}$ & $\begin{array}{c}\text { Average } \\
\text { Population } \\
\text { Affected }\end{array}$ & $\begin{array}{c}\text { Average } \\
\text { Area of } \\
\text { Submergence } \\
\text { per Village } \\
\text { (hectares) }\end{array}$ & $\begin{array}{c}\text { Submergences } \\
\text { per Family } \\
\text { (hectares) }\end{array}$ \\
\hline Gujarat & 3 & 16 & 19 & 4.769 & 19,076 & 374 & 1.55 \\
\hline Maharashtra & 0 & 33 & 33 & 4.301 & 17,204 & 291 & 3.06 \\
\hline $\begin{array}{c}\text { Madhya } \\
\text { Pradesh }\end{array}$ & 1 & 192 & 193 & 37,761 & 151,044 & 108 & 0.63 \\
\hline Total & 4 & 241 & 245 & 46,831 & 187,324 & 153 & 0.92 \\
\hline
\end{tabular}

Source: Sardar Sarovar Narmada Nigam Limited, Government of Gujarat (2015) and Sardar Sarovar Punravasvat Agency (2015)

The author adopted mixed-methods approach and has employed field surveys, participant observations, focus group discussions and key informant interviews as a means for data collection in the study area. Jankowicz (1991), Waghid (2000), and Jayarathe and Stewart (1995) quoted in Manik (2005), viewed that the quantitative and qualitative research approaches should be seen as complementary to each other in the broader social discourse of research are truly significant. In this manner the research conducted was an attempt at reaching complementarity for both the quantitative and qualitative methods by virtue of the research framework that has been specifically designed here. This paper is based on the fieldwork undertaken in the selected resettlement sites of Vadodara, Gujarat viz., Thuvavi, Sathod (A), Sinor-2, Sathod (B) and Dhalnagar as shown in Fig. 3. These sites are diverse in terms of community and their place of origin as evident in table 2. The method of site selection is a combination of random stratified sampling and snowball sampling. Sathod (B) and Thuvavi sites were selected to understand the conditions of resettlers who came from Madhya Pradesh and Maharashtra respectively. Sathod (A), Dhalnagar and Sinor-2 sites were selected to understand the resettlement and rehabilitation of various tribal resettlers from the Project affected parts of Gujarat.

The field surveys were done to assess the impacts of Gujarat's R\&R policy upon the living conditions and socio- economic situation of the resettlers. Furthermore, it helped in identifying the gender issues in planning and implementation of R\&R which was useful for the objectives of the completed research work. The field surveys covered almost all the households in the selected sites as the size of these resettlement sites was small and manageable. As per the Sardar Sarovar Punarvasvat Agency (SSPA) records, the total number of households in these sites was 204, but a total of 167 households (see Table 2) were surveyed as the members of only these households were willing to be part of this study and were available during the time of the survey. The household surveys provided a general comparative picture of the present resettlement site and the original villages in the past. However, this was supplemented with focus group discussions (FGDs) and interviews of both male and female members of the households. These FGDs and in-depth interviews were the important qualitative methods from the point of view of this research paper and gave an insight into the socio-cultural aspects associated with displacement and resettlement. At least two sessions of FGDs at each selected sites were done with small groups of men and women separately. These sessions of focus groups extended to around thirty minutes and discussion revolved around their participation in pre-project consultation, compensation, and problems faced after resettlement and any suggestions for the same. As a follow up to the group discussions, personal interviews were held. In total, 37 respondents were part of these interviews and these interviews were in-depth in nature which helped in understanding the socio-cultural implications of the resettlement. The in-depth interview sample for the study was a 'purposive sample'. Chattopadhyay (2010) also adopted qualitative methods to understand a wide range of issues from the Sardar Sarovar Project resettlers that include their previous histories, problems in compensation and lifestyle changes in resettlement villages. Narratives of the resettlers have been incorporated to understand the post resettlement transformations in social and cultural milieu of resettlers at the resettlement sites. Narratives have been collected from all the five resettlement sites. In simple terms, narrative research is used to answer the question - 'what happened' (Zeller 1995), and to make known or convey information (Lacey 2000).

\section{Study Population}

The five study sites selected for this work are now home to the members of these major tribal groups displaced from the Narmada Valley - the Tadvi', Raathwa², Vasava³ Bhil from Gujarat, Vasava/Bhil from Maharashtra, Bhilala ${ }^{4}$ and Balai from Madhya Pradesh.

The participants in the household census survey, focus group discussions and interviews represented the ethnic diversity of the study area. All the senior resettlers spoke only tribal dialects, some of the younger ones spoke in Gujarati and a little Hindi. Keonji (a tribal resettler and our field assistant) helped in understanding this dialogue in the field. In the initial days of the survey, informal discussions were held with people as part of building rapport with

'Tadvi, also known as Tetariya, are one of the scheduled tribes of Gujarat. According to a local belief, those who live on the river bank (tat) are called Tadvis. Another story is that those who eat the meat of the bird Teta, came to be known as Tetariya. This tribe is largely located in Bharuch, Vadodara and Panchmahal districts of Gujarat.

${ }^{2}$ The name of the tribe has been derived from the term 'rathbistar' which means the forest and hilly areas. Thus the people who are the inhabitants of the rathbistar are called Raathwas. They are spread in Vadodara and Panchmahal districts.

${ }^{3}$ Vasava Bhil from the Bhils is one of the dominant tribes of Gujarat. Bhils commonly use bows and arrows and it is believed that their name emerged from the Dravidian word 'billu' meaning bow and arrow. They occupy the hills of Vadodara district. ${ }^{4}$ Bhilala belong to the Bhil tribal group spread out in Madhya Pradesh. They are inhabitants of Jhabua, Dhar, Barwani and Nimar region of Madhya Pradesh. 


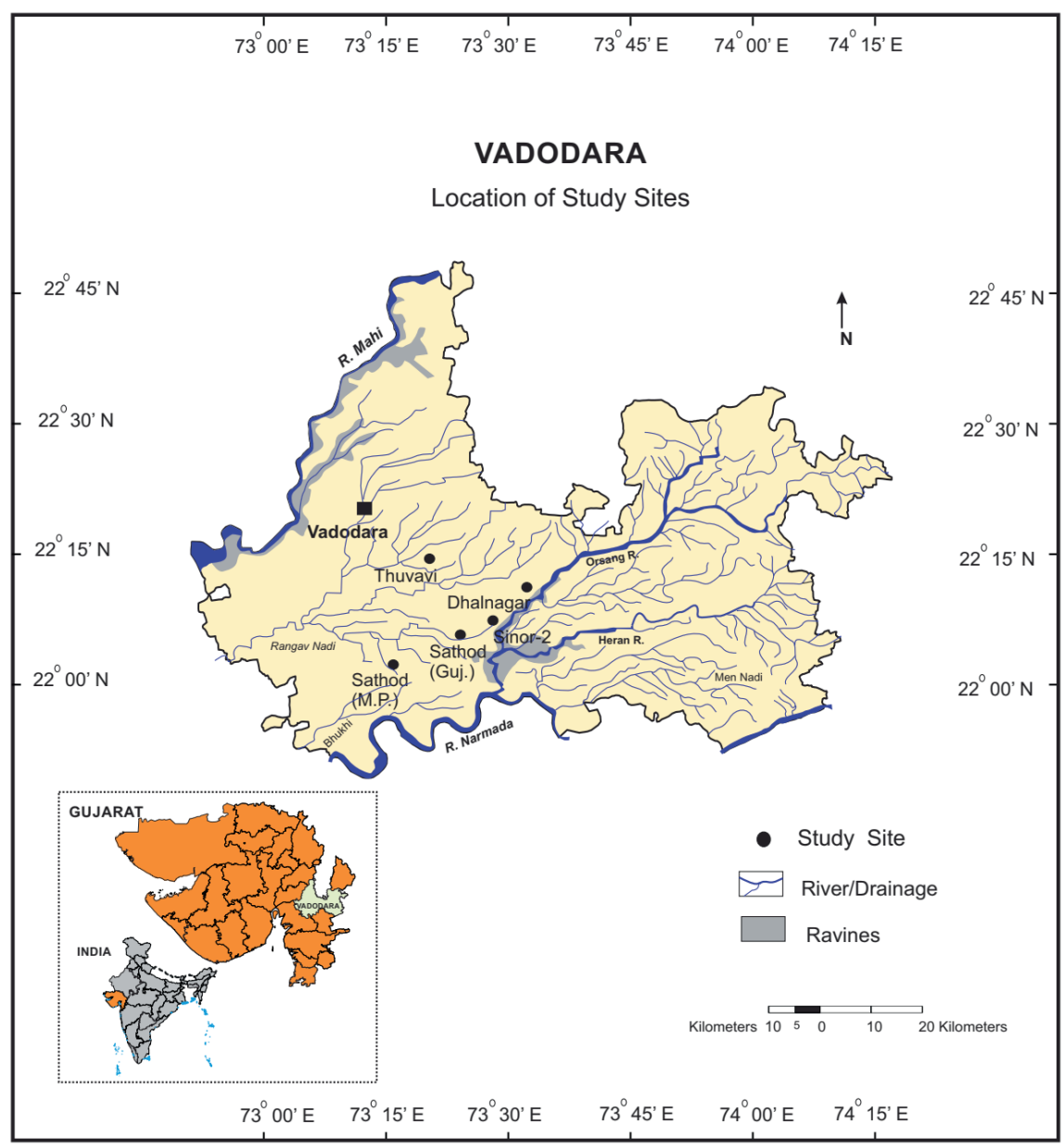

Fig. 3. Location of Study Sites in Vadodara, Gujarat

Table 2. Selected Resettlement Sites

\begin{tabular}{|c|c|c|c|c|c|c|c|}
\hline \multirow{2}{*}{ Resettlement site } & \multirow{2}{*}{ Year } & \multirow{2}{*}{ Total PAFs } & State of Origin & \multicolumn{4}{|c|}{ Resettler Families - Tribal Community* } \\
\cline { 5 - 8 } & & & & $R$ & $T$ & $B$ & $V$ \\
\hline Sathod (A) & $1991-1992$ & 27 & Gujarat & 0 & 0 & 0 & 27 \\
\hline Sathod (B) & $1991-1992$ & 36 & Madhya Pradesh & 0 & 0 & 33 & 0 \\
\hline Thuvavi & $1994-1995$ & 40 & Maharashtra & 0 & 0 & 0 & 40 \\
\hline Dhalnagar & $1991-1992$ & 79 & Gujarat & 74 & 0 & 0 & 3 \\
\hline Sinor -2 & $1999-2000$ & 22 & Gujarat & 0 & 17 & 0 & 5 \\
\hline
\end{tabular}

${ }^{*}$ R-Raathwa, T-Tadvi, B-Bhilala, V-Vasava, O -Others

Source: Compilation from SSPA Village Profiles and author's field work

them. The fact that Keonji was assisting helped in gelling with the resettlers easily. Discourses from daily discussions were transcribed later.

\section{RESULTS AND DISCUSSIONS}

The socio-cultural impacts of displacement and the adaptations between the resettlement sites and the original villages are analysed below.

\section{Family Relations}

The family is the smallest social unit in a village affiliated by blood relation, marriage and co-residence. The resettlers were interviewed to understand if the creation of nuclear families at resettlement sites has strained interfamily relations and every response was in negative. It should be understood in the context that each tribal family had private property owned, leased or occupied by clearing forests in original villages (Mc Cully 2001). There is a tradition of nucleation of the family that usually happens after marriage when the age of maturity is reached by the offspring. The eldest son of the family inherits agricultural lands from the father and does subsistence farming on that land. So, the creation of nuclear families is a common phenomenon in both the original and the resettlement sites. The Gujarat R\&R did not ignore this tradition and stipulated in R\&R policy clause XI 1(3) that all major sons (who were 18 years of age by $1^{\text {st }}$ January 1987) were treated as a separate family. They received five acres of cultivatable land, a house plot, a pair of draught animal and allowance for the construction of the house.

At the resettlement sites, there have been many cases, where eligible members of the same family constructed 
separate houses but mostly lived and ate together in the same house with their parents. According to Vikrambhai (Male respondent, age 45, Dhalnagar site) «many families at their site cultivate the land collectively and thus have higher productivity levels. The land in the backyard of the house was used for growing vegetables. Agricultural land was efficiently managed to grow cash crops». This could be a strategy for coping with the economic ramification of relocation to a new place because their survival was based on land, forest and Narmada (Modi 2004).

Furthermore, there has been no change in relationship with the sons. However, the relationship has become strained between the siblings - those who have got compensation and those who were not eligible according to the cut-off date at the time of compensation. An interesting observation by the elder male members/head of the household was made. Sur Singh (Male respondent, age 70, Sathod (B) site) shared that he has four sons and three daughters. As per the R\&R policy, two sons have got compensation as they were adults and the other two were given nothing as they were minor. The older two sons have got five acres agricultural land each and he himself too, has also got five acres of land. Now at the time of his death, if he divides his land between the younger two sons, they will get 2.5 acre each, while their elder brothers will have much more land. This could create some hostility between brothers and would also be a cause of resentment among his sons ever in the future. It gives us an insight of a brimming issue among the next generation resettlers and could create tensions in the family relations in future.

\section{Dressing Pattern}

«Jaisa des, vaisa bhes»(roughly meaning - when in Rome, do as the Romans do), said Keonji, age 30 of Sathod (A) site while acknowledging the change in their dressing style at the resettlement sites.

The group discussions and participant observation presents an understanding that the traditional dress of tribal men includes a langot (loin cloth) which is worn around waist, phenta (headgear) which was worn on the head and a cover on their upper body consisting of a cloth/sheet. The women cover the waist with kachota or a dark coloured petticoat or short ghagra. Kanchuli (a long flared skirt with a backless blouse with two strings to secure it at the back) is used to cover the top. Odhni (shawl or stole) covers the head and falls at the back (Fig. 4). In terms of ornaments, the women wear kada (bangle) made of silver but kadas of men are of iron. Women also wear the upper arm cuff (armlet/armband) made of silver. Women also wear silver earrings, silver hasadi (choker), necklaces with pendants and silver anklets. Men wear gold or silver earrings and finger rings. Gold ornaments are worn by families who can afford them.

The respondents confabulated during the FGDs that the dressing pattern had begun to undergo minor changes in the original villages itself. But this happened largely among the young and the middle-aged Tadvi men and women who were residing near the dam. "Tadvis were the first to start a change in the traditional way of dressing. This started to happen in the 1960s and 1970s» (Ramabhai Tadvi, Male, age 60, Sinor-2 site). Tadvis were located near the dam site and got exposed to the dress of officials and labourers from other regions at the initial phase of development of the Sardar Sarovar dam (Morse and Berger 1992). Tadvis were also the ones who used to visit nearby markets in towns frequently, and as they also worked on the dam site they had more exposure to contemporary culture (Morse and Berger 1992). Those tribals residing in the interior forest had no exposure to the contemporary dressing style. Men and women of these tribes continued to wear the traditional dress until they were relocated to the resettlement sites.

At the resettlement sites, the dressing practices have completely changed for both men and women. Change of dressing style is an important vehicle of assimilation into the mainstream society. There are two modes of assimilation - either through voluntary adaptation or through forced adaptation. The Tadvi women adopted the mainstream dress code at their original villages as discussed before. This decision was based on their choice signifying a voluntary adaptation. But other adivasi women from Vasava tribe have adopted draping of sari after resettlement out of compulsion, manifesting forced adaptation. This was done because Gujarat's mainstream communities see the tribal dress as bold and considered these women scantily dressed. Social dress codes are based on controlling as well as hiding women's sexuality (Srinivasan 2007). Now at the sites, most of the women are seen in maxi gowns or nighties, which cover their entire body (Fig. 4). «Belonging for women is uniquely linked to sexuality, honour and chastity» (Sangari 1998).

Phishiben (Female respondent, age 50, Sathod (A) site) said that change in dress was essential for them to be enabled to travel comfortably in public transport and while visiting government offices. She recalled an incident that occurred 20 years back when her husband and she were not allowed to board the bus to Vadodara when the bus conductor called them 'adh-nangey'(half naked) as they were in their traditional tribal clothes.

The implication of change in dress in resettlement sites is multiple. It also implies that to a large extent the onus of assimilation of the displaced community into the larger mainstream 'host' community falls on the tribal women. Rupli (Female respondent, age 30, Sathod (B) site) shared how her husband while pointing a finger at the local village women asked her to wear clothes like them. So it is tribal women who in a curious twist are now responsible for protecting the honour of the displaced community as well as that of the local community, and in this complex process, displaced tribal women have now become the de facto property of the local community (Srinivasan 2007).

Vasava men have adopted pants and shirts at new sites as part of the forced adaptation to mingle with the people of the local community. Changing dress and shedding off the tribal identity is an attempt to save them from being ridiculed by the mainstream community. Many other tribal men who used to work at the establishment of a rich businessman (Lala Bhajiyawala) in Dabhoi town (Subdivisional headquarter and at 8-10 Km distance from the site) shared that Lalaji used to tell them that «forget that you are tribals and dress sensibly, or else people will not talk to you, and you will be considered an outcast». The loss of material sustenance and dependence on powerful members of host community ultimately deprives them of their identity and culture (Fernandes 2013), which is visible at the resettlement sites.

\section{Violence against Women}

The UN Declaration of Elimination of Violence against Women (1993) declares violence against women, «as any act of gender-based violence that results in or is likely to result in physical, sexual or psychological harm or suffering to women...» 

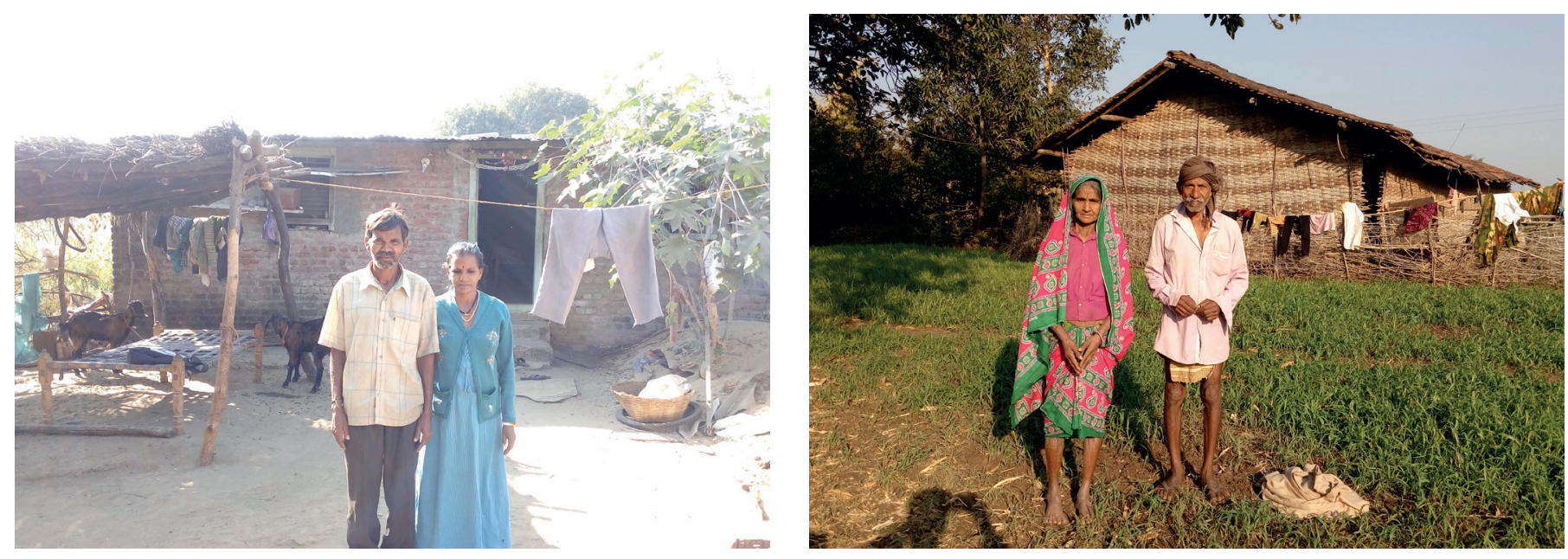

Fig. 4. Changes in Dressing Style at Unsubmerged Villages and Resettlement Site

Source: Author

The households in the original villages witnessed violence against women. In fact, domestic violence against women in tribal communities existed in the original villages much before their displacement and resettlement. However, it was different in terms of degree, frequency and causes of violence as compared to the present situation. The displacement and resettlement into an alien environment has made the issue of violence against women even more complex.

During the in-depth interviews with men resettlers, the reasons cited for this were that the men having lost their bread-winner status (due to displacement) and were not able to feed their family, so in this situation of frustration and helplessness, they resorted to beating their wives. During the initial years of resettlement, this was the prime cause of wife beating. This is an outcome of the emasculinity attached to the frustration of displacement. Patriarchies are extraordinary flexible and find varied means and justifications to reframe roles in a moment of crisis (Srinivasan 2007). Over time, the degree and frequency of domestic violence have somewhat reduced, but the causes of violence against women by men have become varied.

Shraadhbhai (Male respondent, age 40, Sathod (A) site) expressed that «beating a wife is a means to discipline her. This is a new place, therefore, to prevent her from misadventures, sometimes beating acts as a deterrent». He kept mum when asked where he learned about this means to disciplining his wife. «lt is in our culture that a woman takes beatings as well as all benefits/love from the husband» (Nair, et. al. 2000 quoted in Kaur and Garg 2010). It can be gauged that the tribal resettler men came under the influence of the members of mainstream society- the upper caste men and might have started imitating them as a mark of the show of strength. The impact of host communities, both positive and negative, on the resettler community has been studied by Mathur 2009; Colson 1999; Modi 2004. Patriarchal values embedded within the mainstream host society with which the resettler community is settled, interact with the host's prohibitive norms for women (Srinivasan 2007). Drunkenness too is prevalent at all the sites so wife beating in an inebriated state cannot be ruled out.

\section{Marriage Traditions}

The insights from the focus group discussions helped us to understand the marriage practices and tradition in the original villages. It was told that in the original villages, all the tribal communities practiced strict village exogamy and tribal endogamy in marriage. There was a practice of marrying outside the village and marriage alliances were fixed with other villages located within a radius of 10-15 kilometers. Marriage at a young age, before adulthood, was a common practice in the original villages. While responding to a query on the age of marriage in the old villages, Nurajibhai (Male respondent, age 55, Thuvavi site) said «umar hui 15-16 saal ki toh shaadi ho jaati thi, koi dikkat nahi aati thi» (as soon as we turned 15-16, we were married off, there was no problem). Vanjiyabhai (Male respondent, age 50, Thuvavi site) adds that «post-resettlement there is a change in the age of marriage for both boys and girls. In fact, at the resettlement sites the girls' age of marriage is around 16-19 years and the boys' age varies from 18-22 years». There has been a change in the age of marriage due to many reasons cited by the resettlers. Kumtiben (Female respondent, age 60, Sathod (B) site) mentioned that, «for the obvious reasons, a separate room has to be allocated for the newly married couple within the same house. But now this becomes difficult owing to the fact that they have limited household space in the resettlement sites». She adds further that, «in the original villages, they used to make a separate house for the boy before his marriage», which was discussed in the preceding sub-section on family relations. Another reason cited was «early marriages result in early births of children which increases the financial burden of the family, which now, in any case has limited financial resources» (Sarojben, Female respondent, age 40, Sathod (A) site). «Post-resettlement the financial condition of the boy's family plays an important role in determining the age of marriage of boys. Thus, most of the nuptial alliances are fixed after a bumper crop fetches good money» (FGD group, Sinor-2 site). The bride price was the essential condition to be met by the groom's family. In fact, this practice of bride price in the tribal tradition symbolised a relatively high status for women (Fernandes and Menon 1987). A senior resettler from Vasava tribe who also conducts marriage rituals shared that «traditionally as per the patrilocal traditions, a woman has to live with her husband's family after marriage. But the Tadvi and Vasava men who are not able to pay the bride price have to become ghar jamai because their place of marital residence is their in-laws' house». Ghar Jamai means house son-in-law, and the practice is customary disliked in many communities because the men who become ghar jamais are seen as emasculated by taking on the role of a 
woman in some respects (Lamb 2000, Vatuk 1990 quoted in Allendorf 2014). Among the Vasavas, the bride price has increased to Rs. 35000 - Rs. 40000 at the resettlement sites. Besides, 10-20 pitchers of liquor are also given to the bride's family as the bride price to fix a nuptial alliance (FGD group, Sathod (A) site). Similarly, Vyas (1995), in the work on displaced Bhils of Southern Rajasthan also highlighted the similar issue of increased bride price after the resettlement.

During the FGD, it was also told that there has been an increase in the number of ghar jamais at the resettlement sites. The expansion of the ghar jamai role is likely to push the family system toward transformative bilineal, rather than customary patrilineal practices (Allendorf 2014). From a future perspective, it would be interesting to view the impacts of growing ghar jamais in the second and third generation resettlers and, what socio-cultural turn would be witnessed in the tribal society?

\section{Restructuring of Social Networks}

«Displacement is a natural phenomenon as they have to leave their lands. A bride cries when going to her husband's home. The parents also cry, but they know that she must go. It is but natural as once they are there, they will settle down. Then if they have to leave that place again, they will cry again. It happens all the time.»

-Excerpt from 'A Narmada Diary 1995'

A Narmada Diary (1995) is a documentary film by Anand Patwardhan on the people's movement against the dams of the Narmada valley. The excerpt from this documentary mentioned above highlights the stand of a pro-dam male activist, Chunibhai Vaidya. This is very significant as he draws a comparison between displacement due to development and women's migration after marriage due to patrilocal traditions. Comparing the displaced to newly married women, he suggests that they will lament the loss of their place of birth for a few days, but with the passage of time will soon adjust to their new situations. Thus the sorrow of displacement is accepted as natural, transient and momentary. But such comparisons are erroneous because marriage provides women the opportunity to build new relationships and expand their range of identities by becoming mothers, wives and daughters-in-law. However, displacement due to development projects, in contrast, destroys the existing social networks and hinders access to new ones.

For women in tribal areas, kin relationships still constitute the prime avenues of access to scarce resources such as information, economic assistance and other social support (Dyson and Moore 1983). Much of the support provisions flow from close networks: child care, assistance during sickness, access to information, economic assistance and a variety of other support. Women maintain a strong relationship with their paternal families even after marriage and keep visiting their paternal homes for a break as well as on many social functions. Resettlement that takes women far away from their natal home might seriously affect their welfare, as support in times of crisis that might have come from parents and brothers may not be forthcoming due to loss of frequent contact as the natal home and resettlement site are at incraesed distance from each other. It is observed that resettlers are not given a choice in selecting the resettlement site and/or the social unit according to the scattering or clustering methods (Mehta 1992; Morse and Berger 1992; Roy 1999). In the case of the SSP, it is believed that the scattering effect of communities is due to an insufficient supply of plots of land available to accommodate all resettlers (Mehta 1992;
Morse and Berger 1992). If socially cohesive units, from the point of view of women, were not resettled together, it would seriously affect the welfare of women and children (Parasuraman 1993). The women at resettlement villages mourn for not being able to visit their married daughters in other villages, located hundreds of miles away from their rehabilitated villages (Dhagamwar et al. 1995). For instance, a women resettler in Sathod (B) site bemoans the longer distance from her parents place, which she has left behind in Madhya Pradesh and how this distance has reduced the number of visits by her relatives to her home after relocating to this site in Gujarat.

Even the tribal men enjoyed a close relationship with their in-laws. Tribal men informed in the FGDs that there is a practice of spending some days at one's in-laws place to drink and relax there. This also provides them an escape to different surroundings, away from other members of their clan. The resettlement has weakened this bond with their in-laws as the travel now is time-consuming and expensive. Besides, now the tribal men have made friends in non-tribal local communities, this fulfills their need to escape ocassionally to an environment where no member of their clan is present (Inputs from FGDs at Sathod (A) and Dhalnagar sites).

\section{Easing of Social Norms}

A focus group discussion with men at Sathod (A) site revealed that the social control that was part of life in the old villages has somewhat loosened at new sites. Hence in a resettlement site in Sinor, there is an instance of a Tadvi woman living with a Vasava man, something which was taboo at the previous villages.

Keonji pointed towards a man and a woman on a motorcycle, saying that the man was a Raathwa and the woman, a Vasava. They are from the same resettlement site and are married. This mixed ethnic alliance would not have been possible in the hills.

\section{Social Problems}

Drunkenness is a major social problem at these resettlement sites. In fact, some resettlement sites have become havens for the production and sale of illegal liquor in this part of the state (Lobo and Kumar 2009). This unabated alcohol consumption and trading are contradictory to state's rules on prohibition of liquor as Gujarat is a dry state. Actually, the practice of alchol consumption needs to be understood in a historical perspective within the context of tribal customs. FGDs with men resettlers at Dhalnagar, Sathod (A) and Sathod (B) sites revealed that «drinking alcohol has been a part of tribal culture for a long time and it is offered to the deity on important festivals as there is a great cultural value attached to alcohol. Tribal 'devta'(gods) like Ganda Thakur and Phithora in the case of Vasavas and Raathwa communities respectively are believed to consume alcohol. Most of the tribal rituals include alcohol offerings to their revered». However, Keonji (tribal interpreter) clarified further that this alcohol was very different from the one which is now consumed at resettlement sites. The alcohol consumed at original villages was either from palm trees (taad) in the form of toddy or neera. Mahua drink, another intoxicant, was made from fermented flowers of the mahua tree. Both were natural and had several positive effects on the body. In fact, these were consumed for relief from many ailments too. But at the resettlement sites, since these trees are not available, the tribal resettlers started making alcohol 
with gud, sugar, methanol and other synthetic chemical ingredients (Hamjibhai, Male, age 40, Sinor-2). He added that at certain sites resettler men are running the syndicate of bootlegging. This liquor has no health benefits but instead has many negative effects on the mind and body.

Moreover, now this illegal liquor is also sold among the host community. Interestingly, after sunset, the approach road to a resettlement site was the scene of a lot of hustlebustle, probably due to sale and consumption of alcohol at the site (Observation from author random visits to some sites regularly in evening, accompanied by tribal interpreter).

A young resettler (name withheld) involved in illegal liquor making said that he is compelled to do this business as this is the only source of easy money for him. On being asked what the need for so much money is, he replied that at the resettlement sites they are always short of money due to increased expenses. In fact, after his father's death recently, he could inherit only one acre of land as he is the youngest brother among five siblings. This one small piece of land is not sufficient for the sustenance of his family. As he is illiterate, he cannot even get a job. Therefore, he is compelled to resort to such means to earn a living. It was revealed that most of the drop outs from the primary school are involved in bootlegging.

The absence of employment opportunities and the limited earnings from agriculture have forced the resettlers into the business of selling illicit liquor. For many second generation male resettlers, this business of compulsion has become a habit. They are now comfortable with it. They said «demand aati hai, tabhi toh dete hai» (Our supply of liquor is the result of the constant demand).

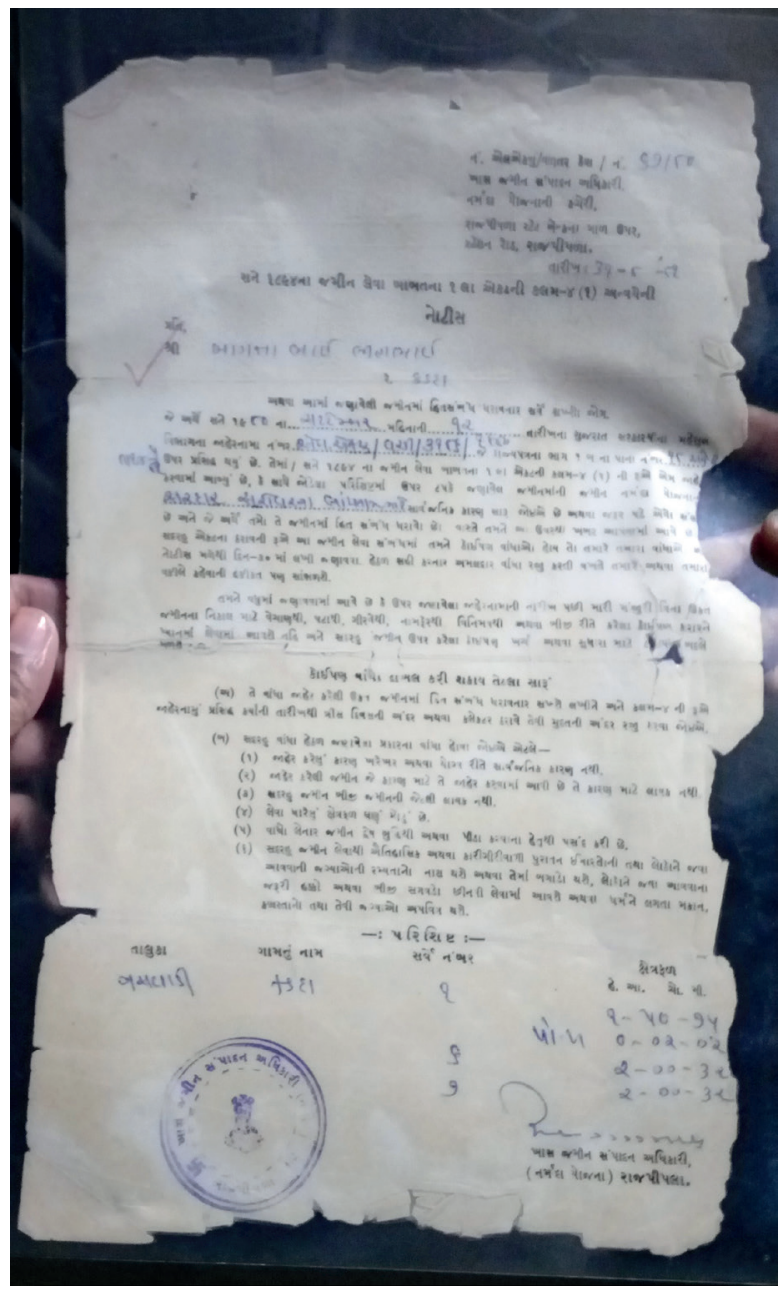

Fig. 5. Eviction Notice Received by Resettler in the Original Villages

\section{Disregard for Cultural Differences}

The literacy rate in the original villages was minimal, and some of the tribals had little or no contact with outside world (Morse and Berger, 1992). With complete disregard for this fact, the project authorities send eviction notices to the resettlers in Gujarati script and in legal language, as is evident from the Fig. 5. Such notices could be difficult to understand even by an educated person.

Furthermore, in the context of socio cultural changes, the loss of folk arts like Raathwa paintings was also noted. These ritualistic paintings are made on the walls and depict various themes of deities of Raathwas and are called Phithora paintings. The Phithora paintings are a hallmark of Raathwa culture and were a part of their everyday life at the original villages. These paintings are a total communication system for the Raathwa community, which is not just the work of art drawn but also written within the culture, as their own ethnography for the culture itself (Pandya 2004). However, the practice of wall paintings has been discontinued after displacement. A respondent from the Raathwa tribe stated that the discontinuation of the practice of wall paintings shows an absence of emotions and a lack of attachment to the new spaces of the resettlement sites.

\section{CONCLUSION}

The above discussion summarizes that the dam induced displacement and resettlement has brought resettlers on the crossroads. The tribal resettlers' sociocultural identity and uniqueness is being transformed due to the exposure of different socio-cultural practices and interaction with host communities. The resettler community has experienced various socio-cultural transformations, which have differential effects on the community. All these intricacies have produced disparate feelings about rehabilitation among the tribal displacees (Chattopadhyay 2010). Moreover, the research brought to the fore that the increased violence against women, problem of drunkenness and bootlegging at the sites and disruption in social networks has exacerbated the dismal situation among the tribal resettlers. The arbitrary and negligent R\&R policies have failed to take the socio-cultural impacts into consideration. The larger economic benefit of the project has swallowed the aspirations, expectations and feelings of the tribals who left their homelands and resettled to new settings. After two decades of the resettlement, the paper is a timely attempt to highlight the long-term impacts of displacement and resettlement. The present work makes it clear that the welfare concerns of resetters are side lined and put some questions that is there a dearth of understanding of the impoverishment risk of the resettlement? And can we ignore sociocultural impacts as an important impoverishment risk of displacement and resettlement?

While drawing inferences from this work, a strategy needs to be drawn for social, cultural and psychological rehabilitation of all affected. It must also compensate, to the extent possible, for the cultural fragmentation and the disruption of social and family relationships. 


\section{REFERENCES}

A Narmada Diary, Film directed by Simantini Dhuru and Anand Patwardhan, 1995.

Aiyar S.S.A. and Kaushal N. (2019). Are Resettled Oustees from the Sardar Sarovar Dam Project'Better Off'Today? Economic \& Political Weekly, 54(12), 23.

Allendorf K. (2014). Fertility Decline, Gender Composition of Families, and Expectations of Old Age Support. Population Research and Policy Review, 34(4), 511-539, DOI: 10.1007/s11113-014-9354-5.

Asian Development Bank (1998). Handbook on Resettlement: A Guide to Good Practice, Manila: Asian Development Bank.

Baviskar A. (1995). In the Belly of the River: Tribal conflicts over Development in the Narmada Valley, New Delhi: Oxford University Press. Bose P., Pattnaik B.K. and Mittal M. (2001). Development of socio-economic impact assessment methodology applicable to large water resource projects in India, International Journal of Sustainable Development \&World Ecology, 8:2, 167-180, DOI: 10.1080/13504500109470073. Centre for Social Studies (1997). Resettlement and Rehabilitation in Gujarat. In: J. Dreze, M. Samson, and S. Singh, eds. The Dam and the Nation, 215-235, New Delhi: Oxford University Press.

Cernea M. (2000). Risks, Safeguards, and Reconstruction: A Model for Population Risks and Displacement and Resettlement. In: M. Cernea and C. McDowell, eds., Risks and Reconstruction: Resettlers and Refugees Experiences, 11-55, Washington D.C.: World Bank.

Cernea M.M. (1999). Why Economic Analysis Is Essential to Resettlement: A Sociologist's View A Economic and Political Weekly, 34(31), 2149-2158.

Cernea M.M. (1995). Eight Main Risks: Impoverishment and social Justice in Resettlement, The World Bank, Washington, D.C.

Cernea M.M. (1996). Impoverishment Risks and Livelihood Reconstruction: A Model for Resettling Displaced Population, Environment Department, The World Bank, Washington, DC.

Cernea M.M. (1997). The Risks and Reconstruction Model for Resettling Displaced Populations. World Development, 25, $1569-1587$.

Chakravorty S. (2016). Land acquisition in India: The political economy of changing the law. Area Development and Policy. 1(1), 48-62,

DOI: 10.1080/23792949.2016.1160325

Chattopadhyay S. (2006). Involuntary Migration and The Mechanisms Of Rehabilitation: The Discourses of Development In Sardar Sarovar, India, Ph.D. Dissertation, Kent State University. 101.

Chattopadhyay S. (2010) Narrating everyday spaces of the resettled Adivasis in Sardar Sarovar. Population, Space and Place, 16(2), 85-

Chattopadhyay S. (2011). Socio-economic transformations of Sardar Sarovar project-affected indigenous populations and post-colonial development state. No. 072. United Nations University-Maastricht Economic and Social Research Institute on Innovation and Technology (MERIT).

Clark D. (1997). The World Bank and development-induced displacement in South Asia. The Brown Journal of World Affairs, 4, 215-231

Clark D. (2009). An Overview of Revisions to the World Bank Resettlement Policy. In: Lyla Mehta, ed., Displaced by Development: Confronting Marginalization and Gender Justice, 195-224, New Delhi: SAGE Publications.

Colson E. (1999). Engendering those uprooted by Development. In: D. Indra, ed., Engendering Forced Migration: Theory and Practice, Oxford: Refugee Studies Program, 23-39.

CSE (1985). The State of India's Environment: First Citizen's Report. Centre for Science and Environment, New Delhi.

Dalal S. (2011). Resettlement and Social Ecology: A Study of Sardar Sarovar Project. PhD Thesis, Jawaharlal Nehru University.

de Wet C. (2006). Risk, Complexity and Local Initiative in Forced Resettlement Outcomes. In: C. de Wet, ed., Development-Induced

Displacement: Problems, Policies and People, 180-202, New York: Berghahn Books

Dhagamwar V., Ganguly T.E. and Singh M. (1995). The Sardar Sarovar Project: a study in sustainable development. In : William F. Fisher.,

ed., Towards Sustainable Development: Struggling over India's Narmada River, 265-290, Abingdon, Oxon: Routledge.

Dorcey T., Steiner, A., Acreman, M. and Orlando, B. (1997). Large Dams: Learning from the Past, Booking at the Future- Workshop Proceedings. Gland, Switzerland. Cambridge and Washington DC: International Union for Conservation of Nature and Natural Resources (IUCN) and the World Bank.

Downing E.T. (2000). Avoiding New Poverty: Mining-induced Displacement and Resettlement. London: International Institute for Environment and Development.

Dwivedi R. (1999). Displacement, Risks and Resistance: Local Perceptions and Actions in the Sardar Sarovar. Development and Change, 30(1), 43-78.

Dyson T. and Moore M. (1983). On Kinship Structure, Female Autonomy and Demographic Behaviour in India. Population and Development Review, 9(1), 35-60.

Fernandes W. and Menon G. (1987). Tribal Women and Forest Economy: Deforestation, Exploitation and Status Change, New Delhi: Indian Social Institute.

Fernandes W. (2013). Tribal or Indigenous? The Indian Dilemma. The Round Table: The Commonwealth Journal of International Affairs,

DOI: 10.1080/00358533.2013.795012.

Gazetteer of the Baroda State 1923, Delhi: SSDN Publisher and Distributors, 2014.

Goyal S. (1996). Economic Perspective on Resettlement and Rehabilitation, Economic and Political Weekly, 31(24), 1461-1467

Guha R. (2005). Prime Ministers and Big Dams, The Hindu. [online] Available at: http://ramachandraguha.in/archives/prime-ministersand-big-dams.html [Accessed 18 December 2005].

Hakim R.P. (1997). Resettlement and Rehabilitation in the Context of Vasava Culture. In: J. Dreze, M. Samson, and S. Singh, eds., The Dam and the Nation: Displacement and Resettlement in the Narmada Valley, 136-167, New Delhi: Oxford University Press.

Hemadri R., Mander H., Nagaraj V. (2000). Dams, Displacement, Policy and Law in India. Thematic Review 1.3: Displacement, Resettlement, Rehabilitation, Reparation and Development, Contributing Paper to the World Commission on Dams, Cape Town: World Commission on Dams.

Kaur R. and Garg S. (2010). Domestic Violence against Women: A Qualitative Study in a Rural Community. Asia-Pacific Journal of Public Health, 22(2), 242-251.

Lacey N. (2000). Narrative and Genre: Concepts in Media Studies. Macmillan: London.

Lobo L. and Kumar S. (2009). Land Acquisition, Displacement and Resettlement in Gujarat: 1947-2004, New Delhi: Sage Publications. 
Manik S.T. (2005). Tribulations and Triumphs of Transnational Teachers: Teacher Migration between South Africa and the United Kingdom, Ph.D. thesis, University of KwaZulu Natal.

Mathur H.M. (2009). Gender Biases in Resettlement Planning, In: Lyla Mehta, ed., Displaced by Development: Confronting Marginalization and Gender Justice, 166-194, New Delhi: SAGE Publications.

Mc Cully P. (2001). Silenced Rivers: The Ecology and Politics of Large Dams, New York: Zed Books.

Menon G. (1995). The Impact of Migration on the Work and Tribal Women's Status. In: Loes Schenken-Sandbergen, ed., Women and Seasonal Labour Migration. 79-164, New Delhi: Sage Publications.

Mishra A. (2019). Issues of Large-scale Dam Resettlement and Rehabilitation: Case of Bilaspur, Himachal Pradesh. Indian Journal of Public Administration, 65(4), 848-868.

Modi R. (2004). Sardar Sarovar oustees: coping with displacement. Economic and Political Weekly, 39(11), 1123-1126.

Morse B.F. and Berger T.R. (1992). Sardar Sarovar: The Report of the Independent Review, Ottawa: Resources Future International (RFI).

Mukherjee B.M. (1990). Loktak Project and Some Basic Issues for the Communities in Manipur Valley. In: V. Sudarsen \& M.A. Kalam, eds.,

The Uprooted: Development, Displacement and Resettlement, 97-106, New Delhi: Gian Publication House.

Padel F. and Das S. (2008). Cultural Genocide: The Real Impact of Development-induced Displacement. India Social Development Report 2008. Development and Displacement, New Delhi: Oxford University Press.

Pandya V. (2004). Rathwa Pithoro: Writing about Writing and Reading Painted Ethnography. Visual Anthropology, 17(2), 117-161, DOI: 10.1080/08949460490430307.

Parasuraman S. (1993). Impact of Displacement by Development Projects on Women in India, Working Paper Series No. 159, The Hague: Institute of Social Studies.

Philip K. (2009). Indian Informational Capitalism: Revisiting Environment and Development Studies. Capitalism, Nature, Socialism 20(4), 73-81.

Reddy I.U.B. (1990). Industrial Development and Problems of the Uprooted: A Case Study. In: V. Sudarsen \& M.A. Kalam, eds., The Uprooted: Development, Displacement and Resettlement, 115-126, New Delhi: Gian Publication House.

Sah D.C. (2003). Social Capital and Governance Evidences from Southwestern Tribal Belt of Madhya Pradesh, Review of Development and Change, 8(1), 41-70.

Sah D.C. and Tomar S. (2011). Sardar Sarovar Project: Some Contentious Issues. In: R. Parathasarathy and Ravindra Dholakia, ed., Sardar Sarovar Project on the River Narmada History of Rehabilitation and Implementation, 2, 380-440, New Delhi: Concept Publishing Company.

Sangari K. (1998). Consent, agency and rhetorics of incitement. In: T.V. Satyamurthy, ed., Region, Religion, Caste, Gender and Culture in Contemporary India, New York: Oxford University Press.

Scudder T. (1983). The Relocation Component in Connection with the Sardar Sarovar Project, Binghamton: Institute for Development Anthropology for the World Bank.

Srinivasan B. (2007). Negotiating Complexities: A Collection of Feminist Essays, New Delhi: Bibliophile South Asia.

Terminski B. (2013). Development-Induced Displacement and Resettlement: Social Problem and Human Rights Issue, University of Geneva Research Paper No. 9. [online] Available at: SSRN: https://ssrn.com/abstract=2026410 [Accessed 9 Jun 2013].

Thatte C.D. (2012) Resettlement due to Sardar Sarovar Dam, India. In: C. Tortajada et al., eds., Impacts of large dams: A global assessment. 259-276. Berlin, Heidelberg: Springer, DOI: 10.1007/978-3-642-23571-9_12.

Vyas N.N. (1995). The Social Consequences of Resettlement on Tribals of Southern Rajasthan: A Case Study of Kadana Project. In: H.M. Mathur, Ed., The Resettlement of Project Affected People- Proceedings of a Training Seminar, 57-78, Jaipur: HCM Rajasthan State Institute of Public Administration.

Whall H. (2004). Peoples' rights in the Commonwealth. Paper presented at Minority Rights and Reconciliation in the Commonwealth: A Cumberland Lodge Conference, 11-13 February.

World Commission on Dams (WCD). (2000). Dam and Development: A New Framework For Decision Making, The Report of The World Commission on Dams, London: Earthscan.

Xaxa V. (2018). Coercive 'Development', Economic and Political Weekly, 53(45), 7-8.

Zeller N. (1995). Narrative Rationality in Educational Research. In: E. McEwan \& E. Egan, eds., Narrative in Teaching, Learning, and Research, 211-225, New York: Teachers College Press.

Websites Referred

http://sspa.gujarat.gov.in/rehabilation.htm

http://sardarsarovardam.org/

http://www.sspa.gujarat.gov.in/

http://www.nca.gov.in/ 